\title{
Chronology of 1910s American Culture
}




\begin{tabular}{|c|c|c|c|}
\hline Date & Events & $\begin{array}{l}\text { Visual Art, Photo- } \\
\text { graphy and Design }\end{array}$ & Film and Vaudeville \\
\hline 1910 & $\begin{array}{l}\text { Mann Act passed, preventing the } \\
\text { transportation of women across } \\
\text { state lines for 'immoral purposes'; } \\
\text { becomes known as the White } \\
\text { Slave Act. } \\
\text { Victor Berger is the first Socialist } \\
\text { elected to the United States } \\
\text { Congress. } \\
\text { Mexican Revolution against } \\
\text { President Porfirio Diaz. } \\
\text { Boy Scouts of America founded. } \\
\text { African American Jack Johnson } \\
\text { defeats Jim Jeffries, 'The } \\
\text { Great White Hope', to retain } \\
\text { heavyweight boxing championship } \\
\text { of the world. } \\
\text { George Herriman publishes first } \\
\text { 'Krazy Kat' cartoon. }\end{array}$ & $\begin{array}{l}\text { International } \\
\text { exhibition of pictorial } \\
\text { photography, } \\
\text { Albright Art Gallery, } \\
\text { Buffalo }\end{array}$ & $\begin{array}{l}\text { Florence Lawrence } \\
\text { stars in The Broken } \\
\text { Oath } \\
\text { John Randolph Bray } \\
\text { patents cel process } \\
\text { for animation }\end{array}$ \\
\hline 1911 & $\begin{array}{l}\text { Triangle shirtwaist factory fire } \\
\text { kills } 146 \text { workers in New York } \\
\text { City, mostly young immigrant } \\
\text { women, and prompts state } \\
\text { reform of fire regulations in the } \\
\text { workplace. } \\
\text { Arizona and New Mexico } \\
\text { admitted to statehood. } \\
\text { United States Supreme Court } \\
\text { breaks up Standard Oil. } \\
\text { National Urban League founded. }\end{array}$ & $\begin{array}{l}\text { John Sloan becomes } \\
\text { Art Editor of The } \\
\text { Masses } \\
\text { Sailing, Edward } \\
\text { Hopper's first } \\
\text { painting to be sold } \\
\text { New York Public } \\
\text { Library Main Branch } \\
\text { opens, designed by } \\
\text { Carrère and Hastings }\end{array}$ & $\begin{array}{l}\text { Al Jolson leaps to } \\
\text { Broadway stardom in } \\
\text { La Belle Paree } \\
\text { Enoch Arden (Dir. } \\
\text { D. W. Griffith) }\end{array}$ \\
\hline
\end{tabular}




\begin{tabular}{|c|c|c|}
\hline Fiction and Poetry & Performance and Music & Criticism \\
\hline $\begin{array}{l}\text { Henry James, The Finer } \\
\text { Grain }\end{array}$ & $\begin{array}{l}\text { Enrico Caruso stars, and } \\
\text { Arturo Toscanini conducts, } \\
\text { at the New York Met in the } \\
\text { world premiere of Giacomo } \\
\text { Puccini's La Fanciulla del } \\
\text { West }\end{array}$ & $\begin{array}{l}\text { Emma Goldman, Anarchism } \\
\text { and Other Essays } \\
\text { Jane Addams, Twenty Years } \\
\text { at Hull House } \\
\text { Theodore Roosevelt, African } \\
\text { Game Trails } \\
\text { The Crisis, the house journal } \\
\text { for the NAACP, founded, } \\
\text { with W. E. B. Du Bois as } \\
\text { editor }\end{array}$ \\
\hline
\end{tabular}

Edith Wharton, Ethan Frome Theodore Dreiser, Jennie Gerhardt Frances Hodgson Burnett, The Secret Garden W. E. B. Du Bois, The Quest of the Silver Fleece
Edward Sheldon, The Boss David Belasco, The Return of Peter Grimm

Irving Berlin, 'Everybody's Doin' It Now', 'Alexander's Ragtime Band'

Nat D. Ayer and Seymour Brown, 'Oh, You Beautiful Doll'

1911-12 Abbey Players' tour of the United States
Ambrose Bierce, The Devil's

Dictionary

Frederick Winslow Taylor, The Principles of Scientific Management The Masses begins George Santayana, 'The Genteel Tradition in American Philosophy' 


\begin{tabular}{|c|c|}
\hline Date & Events \\
\hline 1912 & $\begin{array}{l}\text { June: After failing to gain the } \\
\text { Republican nomination for } \\
\text { president, Theodore Roosevelt } \\
\text { forms the breakaway Progressive } \\
\text { Party. } \\
\text { November: Democrat Woodrow } \\
\text { Wilson wins presidential election } \\
\text { against incumbent Republican } \\
\text { William Taft, Roosevelt's } \\
\text { Progressive Party and Eugene } \\
\text { Debs's Socialists. } \\
\text { The Titanic sinks on its maiden } \\
\text { voyage to New York. } \\
\text { Lawrence, MA Textile Strike, } \\
\text { involving 23,000 workers. }\end{array}$ \\
\hline
\end{tabular}

Visual Art, Photo-

Film and Vaudeville graphy and Design

Arthur Dove's first
one-man exhibition,
at Stieglitz's '291'
Excerpts from
Wassily Kandinsky's
Concerning the
Spiritual in Art
appear in Camera
Work
1912-13 John
Marin's sequence of
watercolours of New
York architecture,
including the
Brooklyn Bridge
and the Woolworth
Building

Ruling against the Motion Picture Patents Company in Latham loop patent case represents an important legal victory for independent production companies Keystone Pictures Studio opens Harry Houdini pioneers 'Chinese Water Torture Cell' escape Keystone's A Noise from the Deep, starring Mabel Normand and Fatty Arbuckle, reputedly pioneers the thrown pie in the face gag Edison's What Happened to Mary? pioneers serial film

191331 March: A record number of immigrants in a single day arrive at Ellis Island (6,745).

Crossword puzzles debut in the New York World.

Sixteenth Amendment to the Constitution passed, making federal income tax constitutional. Ford opens assembly line. Seventeenth Amendment to the Constitution passed, allowing direct election of senators. Federal Reserve Act. Federal Raker Act allows for the flooding of Hetch Hetchy Valley in Yosemite to provide water for San Francisco.

\author{
The Armory Show \\ Opening of \\ remodelled Grand \\ Central Station; \\ completion of \\ Woolworth Building, \\ designed by Cass \\ Gilbert \\ Joseph Stella, 'Battle \\ of Lights, Coney \\ Island' \\ Max Weber, 'Fleeing \\ Mother and Child'
}

\section{Traffic in Souls (Dir. George Loane Tucker)}


James W. Johnson, The

Autobiography of an Ex-

Colored Man

Zane Grey, Riders of the

Purple Sage

Harriet Monroe founds

Poetry magazine

Theodore Dreiser, The

Financier

Sui Sin Far, Mrs Spring

Fragrance
Max Reinhardt, Sumurun

J. Hartley Manners, Peg O' My Heart

Rachel Crothers, He and She

W. C. Handy, 'Memphis

Blues'
Mary Antin, The Promised

Land

A. A. Brill, Psychoanalysis:

Its Theories and Practical

Application

William James, Essays in

Radical Empiricism
Willa Cather, O Pioneers!

Edith Wharton, The Custom

of the Country

Robert Frost, A Boy's Will

Ellen Glasgow, Virginia
IWW co-ordinates Paterson

Pageant to rally support for striking textile workers Frederick Weatherly, 'Danny Boy'

1913-14 James Reese Europe's Society Orchestra records eight tracks with Victor; 1914, publishes Castle House Rag and Castle Waltz
Walter Lippmann, A Preface to Politics

The New Republic founded Ezra Pound, 'Patria Mia' Floyd Dell, Women as World Builders: Studies in Modern Feminism

Randolph Bourne, Youth and Life 


\begin{tabular}{|c|c|c|c|}
\hline Date & Events & $\begin{array}{l}\text { Visual Art, Photo- } \\
\text { graphy and Design }\end{array}$ & Film and Vaudeville \\
\hline 1914 & $\begin{array}{l}\text { Telephone lines link New York } \\
\text { and San Francisco. } \\
\text { America declares neutrality as } \\
\text { World War I begins in Europe. } \\
\text { Ludlow massacre, as twenty die } \\
\text { when state militia attack a striking } \\
\text { miners' tent colony in Ludlow, } \\
\text { Colorado. } \\
\text { Panama Canal opens. } \\
\text { Ford institutes five-dollar, eight- } \\
\text { hour day. } \\
\text { Tampico Affair leads to seven- } \\
\text { month US occupation of the } \\
\text { Mexican city of Vera Cruz. } \\
\text { Federal Trade Commission Act. } \\
\text { Provisional Executive Committee } \\
\text { for General Zionist Affairs } \\
\text { launched in New York, headed by } \\
\text { Louis Brandeis. }\end{array}$ & $\begin{array}{l}\text { Clarence White's } \\
\text { School of } \\
\text { Photography opens } \\
\text { Brancusi has his first } \\
\text { one-man show in } \\
\text { New York, at '291' } \\
\text { Edward Hopper, } \\
\text { 'Soir Bleu' } \\
\text { Marsden Hartley, } \\
\text { 'Portrait of a German } \\
\text { Officer' } \\
\text { First US exhibition } \\
\text { of the synchromist } \\
\text { painters, including } \\
\text { work by Stanton } \\
\text { Macdonald Wright }\end{array}$ & $\begin{array}{l}\text { The Perils of Pauline } \\
\text { (Dir. Louis D. } \\
\text { Glasnier; starring } \\
\text { Pearl White) } \\
\text { Judith of Bethulia } \\
\text { (Dir. D. W. Griffith) } \\
\text { Cabiria (Dir. } \\
\text { Giovanni Pastrone, } \\
\text { Italy) } \\
\text { Gertie the Dinosaur } \\
\text { (Winsor McCay) } \\
\text { First appearance } \\
\text { of Chaplin's Little } \\
\text { Tramp character in } \\
\text { Keystone's 'Kid Auto } \\
\text { Races at Venice' }\end{array}$ \\
\hline 1915 & $\begin{array}{l}\text { Henry Ford develops the tractor. } \\
\text { Ku Klux Klan revived at Stone } \\
\text { Mountain, Georgia. } \\
\text { Lusitania sunk by German } \\
\text { U-boat, killing } 1,198 \text { people, } \\
\text { including } 114 \text { Americans. } \\
\text { US Marines invade Haiti. } \\
\text { Victrola phonograph goes on sale. }\end{array}$ & $\begin{array}{l}\text { Francis Picabia and } \\
\text { Marcel Duchamp } \\
\text { arrive in New York } \\
\text { Arthur Dove, 'Plant } \\
\text { Forms' } \\
\text { Maurice de Zayas } \\
\text { opens his Modern } \\
\text { Gallery }\end{array}$ & $\begin{array}{l}\text { The Birth of a Nation } \\
\text { (Dir. D. W. Griffith) } \\
\text { A Fool There Was } \\
\text { (Dir. Frank Powell, } \\
\text { starring Theda Bara) } \\
\text { Carl Laemmle opens } \\
\text { huge Universal } \\
\text { City Studios in Los } \\
\text { Angeles } \\
\text { MPCC prosecuted } \\
\text { under Sherman Anti- } \\
\text { trust Act } \\
\text { Harold Lloyd } \\
\text { pioneers his } \\
\text { 'Lonesome Luke' } \\
\text { character } \\
\text { The Cheat (Dir. Cecil } \\
\text { B. De Mille) }\end{array}$ \\
\hline
\end{tabular}


Fiction and Poetry

Performance and Music

Criticism

Edgar Rice Burroughs,

Tarzan of the Apes

Walter Lippmann, Drift and

Gertrude Stein, Tender

Watch Your Step (songs by

Mastery

Buttons

Robert Frost, North of

Boston

Margaret Anderson founds

The Little Review

Theodore Dreiser, The Titan

Sinclair Lewis, Our Mr

Wrenn

Willa Cather, The Song of the Lark

Charlotte Perkins Gilman,

Herland

Wallace Stevens, 'Sunday

Irving Berlin, performed by

Vernon and Irene Castle)

Formation of the American

Society of Composers,

Authors, and Publishers

W. C. Handy, 'Saint Louis

Blues'

Morning'

Theodore Dreiser, The

Genius

Ruth St Denis and Ted

Shawn open Denishawn

dance school

Jelly Roll Morton, 'Jelly Roll

Blues'

Al Piantadosi and Alfred

Bryan, 'I Didn't Raise My

Boy to be a Soldier'

Sole read-through

performance of Scott Joplin's

opera Treemonisha
Van Wyck Brooks, America's

Coming-Of-Age

Edith Wharton, Fighting

France, from Dunkerque to

Belfort

Horace Kallen, 'Democracy

versus the Melting Pot' 


\begin{tabular}{|c|c|}
\hline Date & Events \\
\hline 1916 & $\begin{array}{l}\text { Margaret Sanger opens first US } \\
\text { birth control clinic. } \\
\text { Woodrow Wilson re-elected } \\
\text { president against Republican } \\
\text { Charles Evans Hughes under the } \\
\text { slogan 'He kept us out of the war'. } \\
\text { US munitions exports at } \$ 1.3 \\
\text { billion. } \\
\text { German agents cause explosion } \\
\text { at Black Tom Island, New York, } \\
\text { destroying 2,132,000 pounds of } \\
\text { munitions - during the Somme } \\
\text { offensive. } \\
\text { Skirmish between United States } \\
\text { and federal Mexican forces at } \\
\text { Carrizal. } \\
\text { Louis Brandeis becomes first } \\
\text { Jewish member of the Supreme } \\
\text { Court. } \\
\text { Labour leader Tom Mooney } \\
\text { controversially convicted of } \\
\text { murdering ten people in the } \\
\text { Preparedness Day Bombing in San } \\
\text { Francisco. }\end{array}$ \\
\hline
\end{tabular}

1917 Last horse-drawn streetcar withdrawn from the streets of Manhattan.

1 February: Germany resumes unrestricted submarine warfare. 1 March: Zimmerman telegraph published, revealing a German offer of alliance to Mexico in forthcoming war with United States.

6 April: United States declares war on Germany.

5 June: Selective service draft begins. 25 June: Espionage Act becomes law. Literacy test added to immigration statutes, as well as immigration being halted from the 'Asiatic barred zone'.

Jones Act makes Puerto Rico a territory of the United States. Eighteenth Amendment to the Constitution proposed by Congress.

First Pulitzer Prizes awarded.
Visual Art, Photo-

Film and Vaudeville graphy and Design

Paul Strand produces his first abstract photographs Georgia O'Keeffe's first exhibition

First Norman Rockwell cover (of an eventual total of 321) appears on Saturday Evening Post Man Ray, 'The Rope Dancer Accompanies Herself With Her Shadow'; also creates first American Dada assemblage, with SelfPortrait

Forum Exhibition of Modern

American Painters, a key exhibition for American modernist art neglected at The Armory Show Morton Schamberg begins his machine paintings

Society of Independent Artists' Show, which includes Duchamp's

'Fountain' The closure of '291', and last numbers of Camera Work James VanDerZee opens his first studio in Harlem

Charles Dana Gibson becomes director of the pictorial division of the CPI

Charles Sheeler's Doylestown Sequence 1917-18, Joseph Stella, 'Brooklyn Bridge'
Intolerance (Dir. D. W. Griffith)

Famous PlayersLasky merges with Paramount Pictures 20,000 Leagues Under the Sea (Dir. Stuart Paton)

The Poor Little Rich Girl (Dir. Maurice Tourneur, starring Mary Pickford) Buster Keaton's onscreen debut, in The Butcher Boy Rebecca of Sunnybrook Farm (Dir. Marshall Neilan, starring Mary Pickford) 
Fiction and Poetry

Robert Frost, Mountain

Interval

Ezra Pound, Lustra (also

begins Cantos)

H. D., Sea Garden

Carl Sandburg, Chicago

Poems

Ring Lardner, You know

$\mathrm{Me}, \mathrm{Al}$
Performance and Music

First performance of Eugene O'Neill's Bound East for Cardiff

Susan Glaspell, Trifles

Diaghilev's Ballets Russes

tours the United States

Isadora Duncan performs

'The Marseillaise' at the

Metropolitan Opera House
Criticism

John Dewey, Democracy and Education

Randolph Bourne, 'Trans-

National America'

Carter G. Woodson founds

Journal of Negro History

Margaret Sanger, What Every

Girl Should Know
T. S. Eliot, Prufrock and Other Observations

Edith Wharton, Summer

Edna St Vincent Millay,

Renascence

William Carlos Williams, $A l$

Que Quiere!

Mary Austin, The Ford

Abraham Cahan, The Rise of

David Levinsky
Théâtre du Vieux

Colombier's US Tour

George M. Cohan, 'Over

There'

Original Dixieland Jazz

Band's 'Livery Stable Blues' and 'Dixie Jass Band One Step' becomes the first-ever jazz record release

Eugene O'Neill, The Moon of the Caribbees

1917-18, Princess Theatre musicals by Jerome Kern, P. G. Wodehouse, and Guy

Bolton
Joel E. Spingarn, Creative

Criticism 


\begin{tabular}{|c|c|c|c|}
\hline Date & Events & $\begin{array}{l}\text { Visual Art, Photo- } \\
\text { graphy and Design }\end{array}$ & Film and Vaudeville \\
\hline 1918 & $\begin{array}{l}\text { Influenza epidemic kills up to } \\
\text { fifty million people worldwide, } \\
\text { 1918-20, and at least } 675,000 \text { in } \\
\text { the United States. } \\
\text { January: Woodrow Wilson } \\
\text { presents his fourteen points to } \\
\text { Congress, outlining his goals for } \\
\text { the post-war peace. } \\
\text { Summer: initial American troops } \\
\text { arrive in Siberia as part of joint } \\
\text { Allied force. } \\
\text { June: American troops help halt } \\
\text { German offensive on Paris at } \\
\text { Château-Thierry. } \\
\text { September: } 550,000 \text { American } \\
\text { troops in action in St Mihiel } \\
\text { offensive. } \\
\text { September-November: } 1,200,000 \\
\text { American troops in action in } \\
\text { Meuse-Argonne offensive. } \\
\text { Eugene Debs sentenced to ten } \\
\text { years in jail for sedition. } \\
11 \text { November: armistice with } \\
\text { Germany. }\end{array}$ & $\begin{array}{l}\text { Formation of the } \\
\text { Provincetown } \\
\text { Printers } \\
\text { Formation of } \\
\text { Whitney Studio Club } \\
\text { Lewis Hine } \\
\text { dispatched to Europe } \\
\text { to photograph for the } \\
\text { Red Cross }\end{array}$ & $\begin{array}{l}\text { Tarzan of the Apes } \\
\text { (Dir. Scott Sidney, } \\
\text { starring Elmo } \\
\text { Lincoln) } \\
\text { Old Wives for New } \\
\text { (Dir. Cecil B. De } \\
\text { Mille) } \\
\text { Shoulder Arms } \\
\text { (starring Charlie } \\
\text { Chaplin) } \\
\text { Mickey (Dir. F. } \\
\text { Richard Jones and } \\
\text { James Young, starring } \\
\text { Mabel Normand) }\end{array}$ \\
\hline
\end{tabular}


Fiction and Poetry

Willa Cather, My Ántonia

Booth Tarkington, The

Magnificent Ambersons

US Post Office burns five

hundred copies of The Little

Review containing sections

of James Joyce's Ulysses,

claiming it is indecent

\section{Performance and Music Criticism}

Frank Bacon and Winchell Smith, Lightnin'

James P. Johnson, 'Carolina Shout'
First public printing of The Education of Henry Adams Henry James, Within the Rim, and Other Essays, 1914-1915 


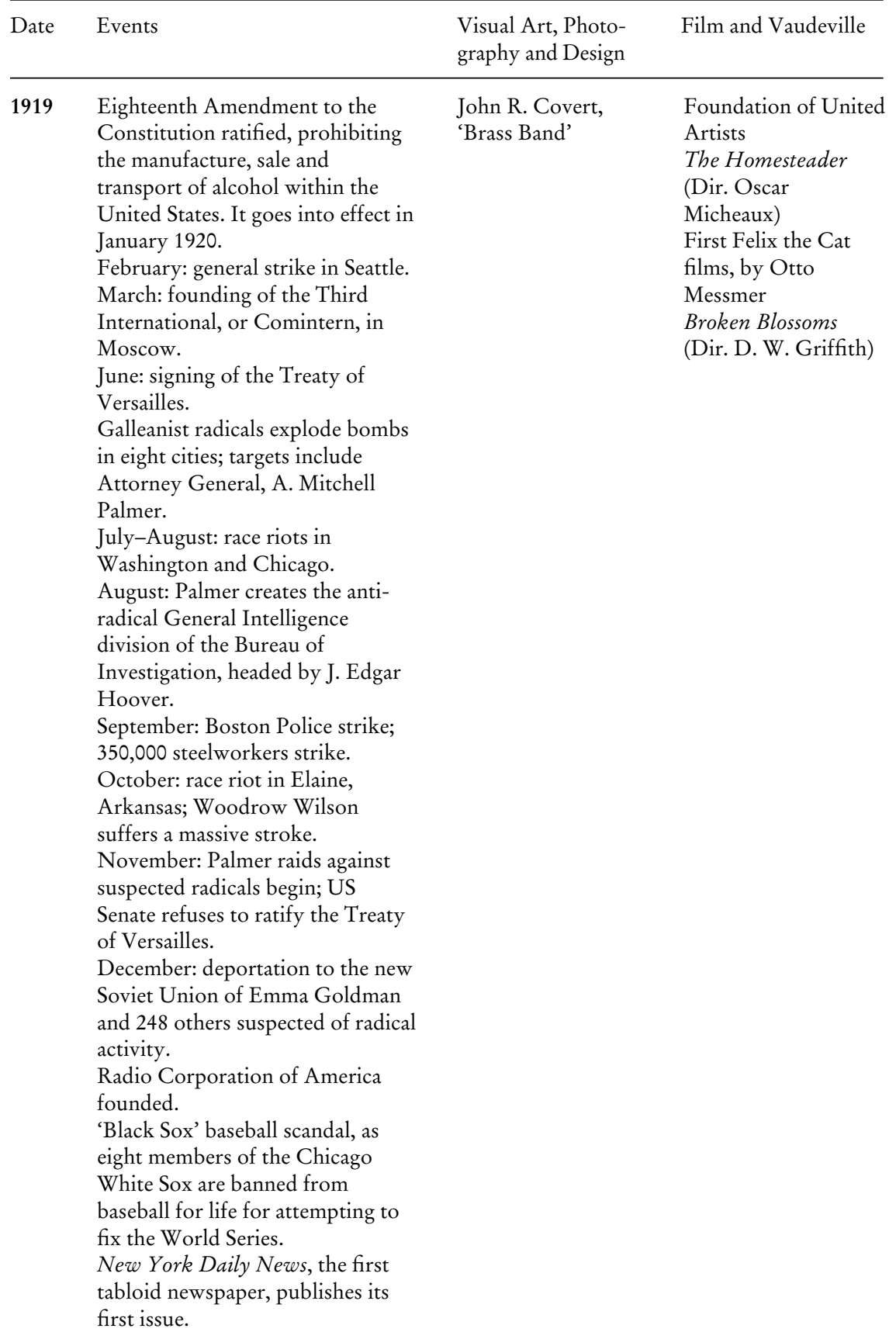


Fiction and Poetry

Sherwood Anderson,

Winesburg, Obio

Upton Sinclair, Jimmie

Higgins

Zane Grey, The Desert of

Wheat

Claude McKay, 'If We Must

Die'

Performance and Music Criticism

Actors' Equity strike

John Kelette and Jann

Kenbrovin, 'I'm Forever

Blowing Bubbles'
Waldo Frank, Our America

Upton Sinclair, The Brass

Check

H. L. Mencken, The

American Language: An

Inquiry into the Development

of English in the United

States

T. S. Eliot, 'Tradition and the Individual Talent'

John Reed, Ten Days that

Shook the World 
